\title{
The Crisis (of Idea) of European Union: Conditions and Possibilities to Overcome
}

\author{
Amra Nuhanović ${ }^{1}$, Jasmila Pašić ${ }^{2}$ \\ ${ }^{1}$ PhD., Faculty of Economics, University of Tuzla, Bosnia and Herzegovina \\ ${ }^{2}$ Centers for Civic Initiatives, Bosnia and Herzegovina \\ Correspondence: Amra Nuhanović, PhD., Faculty of Economics, University of Tuzla, Bosnia and Herzegovina.
}

\author{
Received: May 21, 2019 \\ Accepted: June 19, 2019 \\ Online Published: July 18, 2019 \\ doi:10.5539/ibr.v12n8p53 \\ URL: https://doi.org/10.5539/ibr.v12n8p53
}

\begin{abstract}
Focal point of research is crisis (of idea) of European Union (EU), and conditions and possible directions of its overcoming. The authors have come to very important conclusion, regarding the fact that the Union is facing a great challenge, unity and further integration is needed in order to overcome many weaknesses and ensure further development, prosperity and unity. Building a common European identity, the economic crisis, the euro crisis, the migration crisis, exit of the Great Britain from the EU are all the weaknesses facing the EU and they are posing a threat to EU unity. The sustainability of the EU concept is brought into question and there is an obvious need for changes in its action. Basic scientific methods used in the research: deductive and inductive methods, methods of analysis and synthesis, methods of abstraction and concretization, and economic-historical method.
\end{abstract}

Keywords: crisis (of idea) EU, current situation, possible overcoming trends

\section{JEL Code: F15, G01}

\section{Introduction}

\subsection{Introduction of the Problem Research}

The European Union (EU) is a project of uniting European people with two main motives. The first is to establish stability and lasting peace in Europe through economic and political integration. The second is the creation of a single, integrated market that will enable faster economic development and strengthening the role of Europe in the world economy.

The idea of a united Europe has overtaken philosophers and visionaries for centuries. Among them were Pierre Dubois, Claude Henri de Saint-Simon, Jean Jacques Rousseau, Giuseppe Mazzini, Victor Hugo and Immanuel Kant. History tells us that the idea of united Europe has gained distinct features over the centuries, depending on the political and cultural context. The association "Young Europe" (1834), European Congress for Peace (1876), Pan-European Movement (1926) are just some of the united Europe's movements through history. The period after the Second World War was crucial, when Europe found itself divided on the ideological blocks (capitalist and communist), and the United States, which plays an important role in unification of Europe, sought to stop the spread of communism in Europe by different approaches. Thus, an American foreign policy plan has been implemented to stop the spread of communism, The Truman doctrine, which was later supplemented by the Marshal Plan or the European Renewal Plan ${ }^{1}$

What started as a purely economic union has evolved into an organization that includes a number of policy areas, from climate, environmental protection and health issues to external affairs and security, justice and migration. Today the EU has 28 member states, with more than 500 million inhabitants and 24 official languages, different cultures, customs and history. The creation of a single integrated market required coordination of the macroeconomic, and especially monetary and fiscal policies of European countries. Thanks to the unique market of 28 countries, the European Union is now a major global economic power, and although it accounts for only $7 \%$ of the world's population, the European Union's trade with the rest of the world accounts for around $20 \%$ of

\footnotetext{
${ }^{1}$ Marshal's plan for long has been considered as one of the first European integration processes
} 
world exports and imports. In addition, the Euro, as a common currency, is used daily by 338.6 million people in 19 Member States. Due to the common currency, the European Union has a greater influence in the world, because Euro is the second most important international currency behind the US dollar. Among other things, the single currency has many advantages: elimination of foreign exchange rates fluctuation, conversion costs etc.

However, six decades after its establishment, the EU is confronted with major challenges, ranging from unemployment and economic stagnation to the refugee crisis and the fight against terrorism. Particularly, there are threats from inside the EU, because the United Kingdom decision to leave the EU, which completely undermines the fundamental European idea of cooperation between countries. It all provoked that most EU member states face a "crisis of confidence" in Europe and its institutions. At the same time, nationalist political parties and ideas are increasingly developing, which continuously leads to the weakening of European solidarity. Without a renewed EU vision and effective approach to resolve the crisis, Europe's nationalists will strengthen and continue to destroy the entire project of European integration based on rule of law. Unity in the EU is important for dealing with the crisis. However, today there is very little community between member states and very few areas in which they agree to act together.

Nevertheless, aware of the EU crisis, the representatives of the member states have intensively started the process of "political reflection on the future of the EU". According to the Bratislava Plan, common challenges are recognized in the form of: concerns about migration, terrorism, economic and social insecurity. The Union, after a referendum in the United Kingdom, split into those who advocate the strengthening of integration and those seeking a return of a part of the sovereignty to the member states. The UK's withdrawal from the EU can be an opportunity to redefine relations in the Union. The main problem is - should the EU be only a single market or should it develop into a full political community with elements of federalism? Namely, at the early stage of development, the founders of the European Union considered that economic integration would be the path to political integration, and ultimately lead to the federalization of the EU. Over time, the gradual realization of this concept, or the introduction of transnational elements and institutions into the integration process, was increasingly being carried out. However, the achievement of political legitimacy and integration, without the existence of political identity among citizens, was difficult to achieve. A new integration strategy, which would eventually be able to respond to the EU crisis, must be political, not economically. This suggests that EU evolution should go towards the confederation of national countries, which will be able to deal with common problems and the division of sovereignty in a way that each country is able to control its fate. The creation of confederation of national countries implies a new treaty that will define the Union.

\subsection{Research Question and Research Objective}

The European Union is facing a great challenge and its unity and further integration are needed to overcome many weaknesses and ensure further development, prosperity and unity. Building a common European identity, the economic crisis, the euro crisis, the migration crisis, the exit of the Great Britain from the EU, are all weaknesses facing the EU and posing a threat to EU unity. The sustainability of the EU concept is brought into question and there is an obvious need for changes in its action.

After enlargement from 15 to 25 members, a number of problems arose within the Union, as access of Eastern European countries significantly weakened the awareness of the collective interest. Common values, which existed until then, have been quite "diluted" and different views have emerged on the nature of the state, as well as different views on international politics. At the same time, support of citizens for European integration decreased, and less and less citizens felt that membership is good and that can bring significant benefits.

At the end of the 1980s, advocacy began for development of a European awareness of community and the creation of a common European identity. However, at citizens, creation of a common European identity, begun to create a fear that European identity could jeopardize the national identity. The fact is that the development of a European identity cannot be achieved without major changes in national consciousness. The characteristic of Europe is cultural and traditional diversity, and Jurgen Habermas in recognition of the difference, sees the foundation of a common identity. The idea of European citizenship can not only contribute to the process of European integration, but also to the realization of peace, or mutual understanding throughout Europe. According to Stanković-Pejanović (2011), the idea of a "Europe of Citizens" cannot be realized without the citizens themselves, and is based on a special European identity that is not grounded only on common traditions, history and cultural heritage, but on the project of unification of Europe. In practice, this is concept of the identification of European citizens with "constitutional patriotism", where the foundation of identity is not retrospectively, but is built on the expansion of civil rights and citizenship standards, with the continued enrichment and development of these attributes. 
Thus, one of the basic problems that need to be solved in the dissertation is to answer the central research question: Is the idea of a united EU in crisis today? The fact is that the EU is an important part of the political, economic, institutional and legal reality of the continent. However, the entire manifestation of Europe depends on the vitality of its fundamental idea, that is, its essence. If this idea disappears among European citizens, it can be an end to the EU. Also, the research that will be conducted in this dissertation will try to give answers to the following research questions:

1. How did the process of European integration in the 19th and 20th centuries look like?

2. What has affected the decline of support for the current European integration in the EU member states?

3. What are the key causes and consequences of the crisis that the EU faces?

4. On what way the EU members tried to respond to the challenges?

5. Does the EU have mechanisms to uniquely overcome the crisis?

6. What are the possible scenarios for the future development of the EU?

Based on the current scientific knowledge about the crisis of EU, the theoretical concept of this research is presented in the following figure.
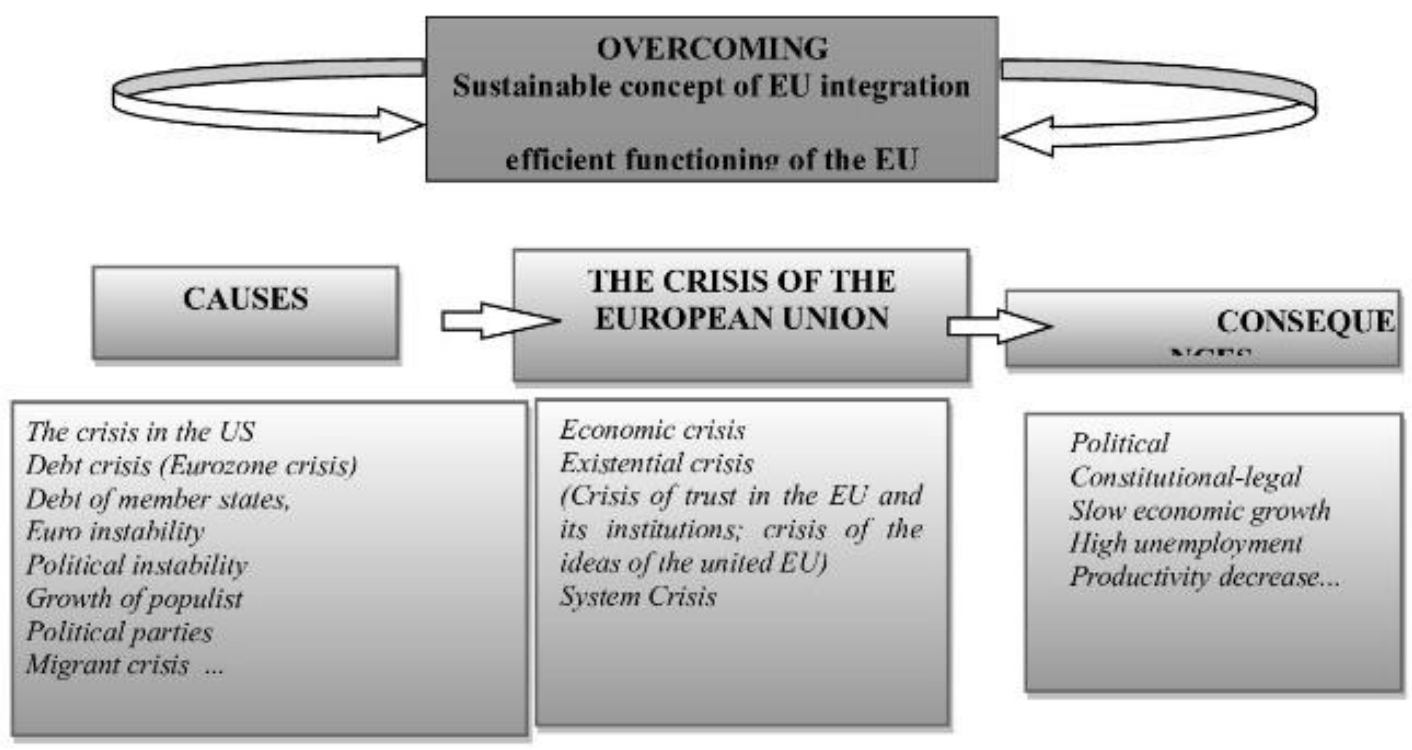

Source: Authors' Research

Figure 1. The theoretical concept of research

\subsection{State Hypothesis}

In accordance with the above-defined object and purpose of the research, central research hypothesis is: Causes and consequences of the EU crisis have a significant impact on integration flows and efficient functioning of the Union.

The paper is organized as follows. After the introduction, the first chapter gives a brief overview of important research results, which deal with the issue of crisis of European Union. The second part refers to a methodology of the study, a third of the results and discussion. In concluding remarks, summarized the main findings of the study.

\section{Literature Review}

\subsection{Theoretical Framework}

On the basis of previous knowledge or experts experience, and in relation to previous research on this topic, in the theoretical framework we can find a significant number of paper, in which each of the authors has a unique way of contributing to the development of this topic through the publication of scientific articles and studies. Most important authors who contributed to this research are, among others: Samardžić, Dullien, Torreblanca, Janning, Rodrigues, Schmitran, Dabić, and many others. A significant part of their theoretical and empirical 
research is dedicated to finding answers to questions on the EU crisis and the possibilities of its overcoming.

Samardzic (2016) discusses the research question - why in the development of European integrations the European civil society did not originate. The author emphasizes that through several decades development of systematic integration of a large number of areas of public life has been accomplished, starting from the common market to monetary union, but that the process was not accompanied by adequate social integration. This issue is gaining momentum in today's crisis.

The Economist Intelligence Unit (EIU), the analytical group, published a report called Europe at the Shooting Frontier that presented seven key issues that threaten the European Union in economic and political terms that could lead to its breakup. Identified issues are: British referendum, Greek debt, monetary policy, and productivity decline, tensions with Russia, party systems, and migrant crisis.

In the study What Is Political Union Sebastian Dullien and José Ignacio Torreblanca discuss three choices on the type of political union that European leaders must bring (Dullien \& Torreblanca, 2012). The first choice is between a limited economic federation aimed at stabilizing the euro and full economic integration that would take traditional national and state tasks such as taxes, social security and redistribution. The second choice is between a federation based on rules with a very small space for innovation and flexibility policies and federations with high discretionary powers and policy instruments. The third choice is between a political system that relies on indirect legitimacy, largely managed through interstate mechanisms, and a political system that relies on instruments of direct legitimacy which empowers the executive powers with supranational institutions such as the European Commission.

The US Congresional Researche Service Report - The European Union: Current Challenges and Prospects states that the European Union is currently facing a series of political and economic pressures, such as slow economic growth and high unemployment in many countries, as well as the rise of populist political parties, that cause to the citizens so called "Eurosceptic" feeling. These factors complicate the Union's ability to deal with a multitude of internal and external challenges, including: Greece's debt crisis, migration and refugee crisis, the United Kingdom referendum on EU membership, an increased threat to terrorism, and many other.

Janning (2018) analyses two types of EU cohesion: 1. structural cohesion (which measures links between member countries, such as: trade flows, participation in common policies and geographical proximity to other EU countries) and 2. Individual cohesion (which measures the engagement of EU citizens). His research shows that there has been significant growth in structural cohesion in Eastern and Central European countries, while individual cohesion has grown mostly in the northern EU countries. However, some countries (France, Italy, Croatia and Spain) experienced both individual and structural cohesion.

Furthermore, Rodrigues (2012) states that the Eurozone faces a systemic crisis with far-reaching consequences for the future of economic and monetary union, European integration and Europe. According to the study, the four main scenarios in the future are possible: (1) member States continue to manage the crisis, which can lead to the collapse of the monetary union; (2) the second variation leads to a further establishment which also affects political integration; (3) a specific combination of factors that can lead to a two-tier European Union with a small hard core of member states; (4) a member state may end the monetary union through a fiscal and political union.

The Solidarity and Strength Study: the future of the EU recognizes that solidarity and strength become key concepts for the future of the Union. Without solidarity and cohesion, it has no ability to act inside or outside the Union. The debt crisis has shown the need for increased coordination and integration, while at the same time support for the united union with increased solidarity is decreasing. Many citizens are under the impression that a new dimension of European integration involves significantly higher centralization and risk.

Rood (2017) in his research concluded that the EU is going through a very difficult period of its existence, as a result of the crisis of confidence that the Union faces. He explains this in a way that, on the one hand, there is a reduction of trust among citizens and parts of the political establishment in the EU as a sphere of governance, and on the other hand, reduction of trust among citizens in political order of their country.

Critical analysis of five scenarios on the future of Europe is particularly represented in paper of Adler-Nissen (2017). Namely, the author advocates a reformist vision of the EU future, which should begin with a new constitutional process, on the basis at which the EU would be reconstituted as a union, or a special federal constitutional form, embedded in the normative spirit of pluralism.

Schmitran (2016) argues that the model of integration promoted by Jean Monnet in the period after the outbreak of the systemic crisis in 2005 in the European Union showed its contradictory properties. The need for a quick and efficient decision-making system marginalized the European Commission and emphasized the European 
Council as a key political institution. The Lisbon Treaty, which came into force on December 1, 2009, further complicated already complex process of policy and decision-making within the European Union. Due to the great disagreement of member states in terms of further development of the Union, differentiated integration is imposed as the future dominant model of integration.

Dabic (2016) state that the crisis sparked discontent, both in terms of legitimacy and the impact of joint European institutions, and required the need for a more serious and far-reaching reform of the governance system of the European Union. It is required that the process of adopting decisions in the Union be made more efficient and more democratic at the same time, which are two political values that are not easy to reconcile and accomplish. In this paper, the view is that the necessary institutional reform at the Union level, to a large extent, hinders the lack of legitimacy for its implementation. The current European elites do not have a clear political vision, nor a solution to undertake measures that the governance system would do to largely democratically responsible citizens.

On the other hand, De Witte \& Heritier (2012) states that the economic crisis has erased the progress of European economies achieved in the years before the crisis. Stable economic growth and employment growth that characterized decades before the crisis have disappeared. In conditions of growth and economic prosperity, the asymmetry of the European Union and the Eurozone did not create major problems. However, the economic crisis in the European Union has had a more pronounced intensity and longer duration compared to the US and an unequal intensity for individual member states of the European Union

\section{Research Methodology}

In the planned research, formulation and systematic processing of scientific facts, in accordance with the framework of certain theoretical and methodological considerations, different methods and techniques of scientific research will be used in the doctoral dissertation. The general methods of scientific research, ie the basic methods of logical and scientific knowledge, as well as their combination, are distinguished and suitable for the subject of the research.

In this context, the following qualitative methods of research will dominate in some parts of the work: basic methods of scientific description, collecting and arranging facts, formulating individual statements, then methods of economic analysis and logical conclusion and understanding. A historical method will be used for theoretical-methodological analysis and evaluation of the observed research problem. When concluding, methods of analysis and synthesis, comparison method, methods of induction and deduction, classification method, and generalization and concretization methods will be applied. A method for a systematic approach (holistic approach) will be used to successfully carry out research as well as to formulate the basic framework for the possible overcoming of the crisis.

\section{Results and Discussion}

The authors came to the very important results, and this is actually a fact, that the crisis of EU should be viewed as:

\section{$\checkmark$ Economic crisis (Eurozone debt crisis);}

$\checkmark$ Existential crisis (a crisis of confidence in the EU and its institutions, a crisis of the idea of a united $\mathrm{EU})$;

\section{$\checkmark \quad$ System Crisis}

Followed by an explanation for each item individually:

The economic crisis that spilled over into the European Union from the US in 2008 confirmed what was already apparent, after the failed referendum and the failure to implement the Treaty on the Constitution for Europe, that the Union entered a new phase of integration, the phase of the crisis. The economic crisis has also revealed fundamental weaknesses and new challenges, as well as the need to further strengthen integration processes. Weakening and crises of the euro as a currency caused a justifiable concern about the future of the Euro as a single currency. Over time, the Euro has become a source of tension and a threat to a united EU. It is believed that the crisis in the Eurozone has revealed deep political disagreements and different visions on the future of the EU, with politicians much louder in attitudes what they don't want, instead of concrete proposals to get out of the crisis. A special threat to the EU is further fragmentation between individual countries and regions, and an increasingly divisive division to the north and south. This division of the rich north and the poor South is even more dangerous, since it begins to receive the outlines of two opposing paradigms. The first one comes from the north and says that they are guilty themselves because of spending more than they should and that now they have 
to pay the price themselves through horrible unemployment rates, stagnation, decline in GDP and unprecedented austerity measures. The second one comes from the so-called. PIGS' countries, which ultimately demand that spending in the past should be divided according to the economic strength of the member states.

The crisis facing the EU is primarily defined as an existential crisis, or a crisis of the idea of a unified Union. Within the Union, today many factions are evident, deeply divided, far from the vision of their founder, and there is an insufficient communion among member states. EU citizens feel less and less unity, solidarity and belonging, and are increasingly moving away from the idea of a united Union. Also, there is a high degree of dissatisfaction among European citizens, due to erosion of social rights, large social differences between individual member states, as well as within the countries themselves. The crisis in the EU, in fact, runs from the collapse of the European Constitution. At a time when it seemed that after Lisbon Treaty from 2007 will come a stabilization period, a new crisis emerged linked to the economic problems that more than half of the Union's members faced. Combating the consequences of the crisis has spawned a series of political and constitutional-legal effects on the EU's fiscal consolidation. On the other hand, there is an increasing rise in euro scepticism in a large number of countries, especially those countries affected by the crisis. It is particularly growing in the United Kingdom, where, due to the will of citizens, the Lisbon Treaty clauses will be applied, by which the possibility of a country leaving the EU is introduced. The other side of such a federalization of Europe is the growth of regional entities - Catalonia, Scotland, Moravia and others. Regions increasingly show the desire to function as independent political subjects, with as much independence of countries. The referendum for the United Kingdom's withdrawal from the Union also significantly disrupted European unity and deepened the crisis, creating the possibility of the so-called „domino-effect” between other EU members. At present, the Union faces the largest uncontrolled migration flow, and the main migration flows are directed towards highly developed countries and areas of the EU. Furthermore, it is surrounded by geopolitical conditions in which it is unable to cope, or that its member states act uniquely, with migrants that cannot integrate, an increasing danger of terrorism, but an unwanted need for growth, development and competitiveness. Today's Union functions in conditions in which every day in which it deals with itself means the loss of a step with innovation and investment, in which other economic (and military) forces are very successful.

The Eurozone also faces a systemic crisis, with far-reaching consequences for the future of economic and monetary union, European integration and Europe. The systemic crisis has shown that the existing model of integration is inadequate. In other words, the need for a quick and inefficient decision-making system marginalized the European Commission and emphasized the European Council as a key political institution. The Lisbon Treaty, which came into force on December 1, 2009, further complicated the already complex policy process and decision-making within the EU. Due to the great misunderstanding of the member states in terms of the development of the Union, differentiated integration is imposed as the future dominant model of integration in resolving the systematic crisis.

\section{Conclusion and Recommendations}

The European Union has gone through a difficult and long way of integration, and the motives for integration have been the evolution of Europe into an integrated, single market that will enable to faster economic development and establish lasting peace and stability. However, this idea of a united EU is in crisis today.

Solidarity and cohesion, as key principles in the functioning of the EU, can and should be important principles in overcoming the current crisis. European countries must become aware of the importance of co-operation and solidarity, and jointly develop a vision for development in the future. EU members need unity and integration in order to overcome the existing numerous weaknesses and ensure prosperity. If the EU wants to survive, it needs to overcome numerous challenges, create a common vision and define a new concept based on European values. For the future progress of the Union, fundamental changes are needed, in which consensus is needed between the member states that will continue the process of transforming the European system of countries into the ever stronger nations of the people. Various ideas have been revived to transform the institutional and contractual framework of the Union (eg "Europe in higher speeds"), but it is more prominent that as a model for a potential solution of the crisis is more and more cite as need for federalization, ie introduction of a higher level of integration of tax and financial systems, at the same time, and higher level of political integration. This argument is based on the fact that some countries have shown incompetence and incompatibility from the aspect of controlling financial transactions. There is also discussion for change of Treaty framework, where only Germany as the economically most stable and politically strongest force would stand out in the foreground, in an effort to adapt the entire economic space to its needs.According to European Commission President Jean-Claude Juncker: "Solidarity is a glue that the Union is holding together." 
Today, the member states of the Union no longer advocate a European project, but national programs, and in order to continue to function successfully, the European Union needs a clear vision in which European values will again occupy a central place. It is necessary to forget the rivalry between jurisdictions and institutions, and work on strengthening unity and communion.

The existential crisis with which the European Union faces is a crisis of the idea of a united European Union. European Commission President Jean-Claude Juncker, in his speech on the state of the Union, said in September 2016 „European Union, at least, is in an existential crisis. Never before has such a division and so little community in the Union been seen. It is important to make an important decision - to get into a collective depression? Is it allowed to let the Union collapse before the eyes?

In the past six decades, integration has been progressed continuously, but it is wrong to conclude that during that period there were no interference or obstacles. The history of European integrations is the history of crises and their retaliation by finding new solutions and a new commitment to integration pillars. If the European Union wants to survive it is necessary to overcome the many challenges, create a common vision and define a new concept of the European Union that will rest on European values. For future progress, full and essential changes are needed, for which the widest possible consensus among member states is to be achieved, which will continue the process of transforming the European system of states into an ever stronger union of nations.

The European structural weaknesses are completely abolished. Hence, enhanced co-operation of economic policies in the euro zone should ensure a successful global exit from crisis (of idea) of the European Union. The European Union must react in the near future in order to avoid its decay.

In this regard, we can draw a few points from the current situation:

$28 \mathrm{EU}$ member states are extremely interdependent. In simple terms this means that, the crisis has highlighted the close links and spill-over between national economies, especially in the euro area. Reforms, or lack of it, in one country affect the impact of all others, as the recent events have proved. The crisis and serious restrictions on public spending have made it difficult for some member states to invest in the basic infrastructure needs in areas such as transport and energy, not only to develop their own economies but also to help them fully participate in the internal market. Therefore, coordination within the EU should be crucial. In fact, the last ten years of events in the EU have only shown and proved that no country alone can effectively respond to the challenges.

$\checkmark \quad$ The EU will influence decisions regarding global policy only if it acts with common forces. Stronger outward presentation must be associated with stronger internal coordination.

$\checkmark \quad$ Europe has left a clear but difficult choice - or to face with immediate challenge of recovery and long-term challenges - globalization, resource constraints, aging - to compensate for recent losses, regain competitiveness, boost productivity and put the $\mathrm{EU}$ on the road to progress ("sustainable recovery"). Or to continue in a slow and largely uncoordinated rhythm with reforms, and thus risk ending with a permanent loss of wealth, a slow growth rate ("bad recovery") that can lead to high rates of unemployment and social misery and a relative fall in the world scene (" lost decade ").

\section{References}

Adler-Nissen, R, Galpin, C., Rosamond, B. (2017). Performing Brexit: How a post-Brexit world is imagined outside the United Kingdom, The British Journal of Politics and International Relations, 19(3), 13

Dabić, D. (2016). Mogućnost upravljanja institucionalnom krizom EU, Informacioni centar EU, Beograd, pp.18

De Witte, B., \& Heritier, A. (2012). the Euro Crisis and the State of European Democracy, the European Union Democracy Observatory, Italy, pp. 7.

Dedman, M. J. (2001). the Origins and Development of the European Union 1945-95 (A History of European Integration), Taylor \& Francis e-Library, pp. 4-8.

Dinan, D. (2010). Mijenjanje Evrope - Istorija EU, Službeni glasnik Beograd, pp. 6.

Dullien, S., \& Torreblanca, J. I. (2012). What is political union?, The European Council on Foreign Relations (ECFR), pp. 5-6.

Europe stretched to the limit. Retrieved from https://www.eiu.com/public/topical_report.aspx?campaignid=EUFuture, mart 2019.

Janning, J. (2018). Crisis and cohesion in the EU: A ten-year review, European Council on Foreign Relations (ECFR), United Kingdom, pp. 11-12. 
Rodrigues, M. J. (2012), Mapping Future Scenarios for the Eurozone, Friedrich Ebert Stiftung, Berlin, pp. 8-9.

Rood, J. (2017). A crisis of confidence in the European Union? Netherlands Institute of International Relations Clingendael, pp. 5.

Samardžić, M. (2016), Demokratski deficit EU - između zahteva za dubljom legitimnošću odluka i efikasnosti sistema, Informacioni centar EU, Beograd, pp. 8.

Samardžić, S., \& Milosavljević, I. (2013), Evropski građanin u vremenu krize, Zbornik radova s naučnog skupa „Evropski građanin u vremenu krize: izbor između EU i države članice kao lažna dilema“, Univerzitet u Beogradu - Fakultet političkih nauka, Beograd, pp. 4.

Samardžić, S., \& Milosavljević, I. (2014). Kriza EU, Službeni glasnik Beograd, pp. 2.

Schmitran, T. (2016). Kriza procesa upravljanja u EU- da li opstaje metod integracije Žana Monea? Informacioni centar EU, Beograd, pp. 3.

Solidarity and Strength: the future of the EU. Retrieved from https://www.boell.de/en/content/solidarity-and-strength-future-european-union

Stanković-Pejnović, V. (2011), Ka evropskom građanstvu, Teme, 35(4), 5-6.

Tejlor, P. (2010). Kraj evropske integracije, Albatros plus, Službeni glasnik Beograd, pp. 3-4.

US Congressional Research Service. Europe Union: Current Challenges and Perspectives. Retrieved from https://fas.org/sgp/crs/row/R44249.pdf

\section{Copyrights}

Copyright for this article is retained by the author(s), with first publication rights granted to the journal.

This is an open-access article distributed under the terms and conditions of the Creative Commons Attribution license (http://creativecommons.org/licenses/by/4.0/). 